\title{
Margaret Atwood: A Sound Ecologist
}

\author{
Dr. Ratnesh Baranwal \\ Assistant Professor in English \\ K.N.I.P.S.S. \\ Sultanpur, U.P., India \\ ratnesh25373@gmail.com
}

\begin{abstract}
This paper is an attempt to explore the ecological issues in Margaret Atwood's novels. She happens to raise her voices against the demolition of the forests, advocating very strongly to pay attention to ecological principles for the preservation of the environment for the future generation. She tends to express her deep sense of anxiety over the ecological issues as depicted in The Handmaid's Tale (1985) and again in the stories and fables of Wilderness Tips (1991) and Good Bones (1992). Her novel - Surfacing (1972) begins and ends with the forest starting like a detective story. Her most significant search-operation begins when she happens to dive into the lake, looking for the Indian rock paintings recorded in her father's drawings in chapter 17 of the novel. Environment or wilderness strongly figures out in her fabric of Canadian identity. It has multiple functions : as a marker of geological location, as a spatial metaphor and as a popular cultural myth of Canada. Geographically, it is defined as 'wild uncultivated land'. She rediscovers the White English - Canadian construction of identity, charting a distinctive New World positioning in relation to history, geography and culture suggestive of continuity between immigration narratives and a contemporary awareness of psychic location. Environment
\end{abstract}


holds a very significant place in her portrayal of Canadian identity. She personally holds a bitter experience of Colonialism and its outcome on Canada and Canadians in the post-colonial era. Her fiction comprises of several post-colonial themes such as survival, hybridization, isolation, hegemony, displacement, loss of identity, banishment, multiculturalism, homelessness, colonization of the mind and of the natural world. Thus this paper seeks to analyze the different shades of ecology and ecocriticism exploring the organic unity between the man and the environment. This theory has gained a great importance since last few years. The ecological balance between the human and environment is shattered. People have deviated from their moral duties towards nature. Thus as a sound observer of ecology, she finds out the misuse and colonization of the natural world.

Keywords: Ecology, nature, environment, wilderness, post-colonial

Margaret Atwood happens to be a sound ecologist. She was born on $18^{\text {th }}$ Nov., 1939. She is very much reputed as a great Canadian poet, novelist, literary critic, essayist, inventor, teacher and environmental activist. Her famous novels are - The Edible Woman (1969), Surfacing (1972) and Lady Oracle (1976). Her more recent novels are Bodily Harm (1981) and The Handmaid's Tale (1986). Her growing interest in Canadian nationalism and in feminism has made her a significant figure in the contemporary Canadian culture. Her other novels are - 'Life Before Man' (1979) and Cat's Eye (1989). Her works mainly deal with the ecological issues and association between humans and environment. Since her childhood, she has made a very close association with the Canadian wilderness. Her father happened to be a professional forest entomologist which facilitated her relationship with the wilderness of Northern Quebec. Her famous novel- Surfacing delineates the tale of the two expeditions - an expedition into the 
internal mindscape of the anonymous female narrator and the expedition into the external landscape of Canada. The hero of the novel is searching out her identity and ends with her unification with nature after discarding all symbols of culture. She intends to highlight the unfair power structures that are causing mass destruction like the anthropocentric greed of humanbeings, especially the American consumerism.

Canada is associated with the literary commonwealth of English-speaking nations. Canadian literary traditions have had their roots in England, France and the United States. By the early $19^{\text {th }}$ C., Canadian writing gained momentum with the hallmarks of assertion and strength. A sound study of the heterogeneous cultures of Canada responds a microcosmic view of this universe and the potential of the solidary of the people of the whole world. The distinguished enlighteners of Canadian poetics are Douglas Gordon Jones, Margaret Atwood and John Moss etc. There writers tend to propound that the literary texts are an outcome of a culture that has an organic unity of symbols, images and myths. Atwood has earnestly raised in her novels the ecologistical issues of the Canadian cultural identity. Infact, this quest for identity is an effort to break away from the colonial past and lay down new critical paradigms and parameters for Canadian writing. There is a strong parallel affinity between the Canadian culture and that of India regarding customs, traditions and conventions. The multilingual and bilingual practices in both of these countries tend to provide an atmosphere of unity in diversity. In both of these countries, phallocratic system is prevailing where sexual colonialism still dominates. It is very tough situation for a woman to maintain her dignity, chastity and selfesteem in such a male-dominated set-up. A sexist culture comes into being where there occures a power-disbalance between the two sexes-the male being the colonizer and the female being the colonized. Thus females are marginalized in Canada. This one is the patriarchal civilization that 
defines a woman as a marginalized creature. Having been treated as a marginalized creature, the Canadian woman feels very much closer to the cultural milieu of Canada than the Canadian man.

In Atwood's novels, many beautiful images, pictures concerning environment have been portrayed. She strongly speaks :-

"You came out of something, and can then branch out in all kinds of different directions, but that does not mean cutting yourself off from your roots and from your earth" (Conversations, 143)1

She sprinkles out the fragrance of ecologistic sensibility in her famous novel 'Surfacing', when she happens to see a strange blurred image, which might or might not be her father's drowned body. But such a image has so far not been depicted in the story of the novel. It reveals a fairy tale, being at the centre of the novel. There is no description about a marriage, nor a child, only an affair and an abortion. The narrator says:

1. Earl G. Ingersol, ed. Margaret Atwood : Conversations (London : Virago, 1992)

"I could not accept it, that mutilation, ruin I had made, I needed a different version" $(143)_{2}$

The occidental colonization comprises possession of land occupied by human beings along with the natural world and its biotic communities. According to Garrard -

“America's rapidly growing wealth in $19^{\text {th }} \mathrm{C}$. was based on destruction and consumption of forests and wildlife so astonishingly voracious that in places, it announced to an ecocidal campaign to exhaust and refashion whole habits".3 
The unknown hero of 'Surfacing' echoes exactly this thought when she beholds the “white birches dying” and the city has "swelled enough to have a bypass".(Atwood)3

She travels down the familiar road to home after nine years. She could notice bulldozed trees with their roots hanging out. She feels very much sad, having found the current state of the dying birches, the growing cities encroaching into the green world. The natural world suffers the joint torment of being encroached upon, uprooted and dislocated.

As a deep ecologist, she finds out the idiocy linked with the killing. While killing a human by another human is treated as a punishable crime, killing certain things is regarded reasonable and appropriate. While remembering her infancy, she keeps recalling that

\section{Margaret Atwood, Surfacing (Virago : London, 1979)}

\section{Garrard, Greg, Ecocriticism, London/New York : Routledge, 2007, print}

being kids they had been taught that carnage was erroneous and that just enemies and food could be carnaged. She is very much irritated with the Americans. Utterly unconscious of their moral duty towards the natural world, the western countries start depleting natural resources under the process of eco-colonization. They have neither Wordsworthian respect for the natural world nor do they have a simple respect for it.

The term 'Post-colonialism' is treated as interdisciplinary in English literature. It does not stand isolated from the literary text, and nor does it study in a vacuum, but rather it maintains the interrelationship among the other relevant disciplines such as the sociological, historical, the cultural, the political and the economic. Margaret Atwood happens to be a very promising postcolonial writer who maintains a bridge between the Canadian literature and culture and those of India through her novels. The pattern of the Cultural Revolution in the post-colonial era is divided into three phases. In the first one, the native intellectuals assimilate the culture of the 
occupying power, in the second one, he sustains his authentic identity and in the third one, he keeps fighting against the occupying authority and deeply motivates his own people by virtue of his writing by creating intellectual consciousness. In such a process, consequently, there does occur the intermixing of different cultures, i.e. multi-culturalism in the post-colonial era. It gives birth to a 'hybrid-culture' affecting the literature. There is an organic unity between culture and literature and literature itself is the reflection of culture. Loss of culture is the loss of literature. Dignity of literature is depending much more upon the dignity of culture. Such a quality is traceable in her novels.

Bill Ashcraft has minutely observed:-

"Post-colonial culture is inevitably a hybrid phenomenon involving a dialectical relationship between the grafted European cultural systems and an indigenous ontology, with its impulse to create or recreate an independent local identity”.4

Atwood has maintained her global identity as a sound ecologist through her marvellous talent and skill. A number of talented female writers have come out with flying colours in the galaxy of English literature in the contemporary period since 1950. Some of them figuring out are - Mavis Gallant, Margaret Laurence, Alice Munro and also Margaret Atwood. Atwood happens to point out a dialectical relationship between a culture and its art. She realizes that art remains both dependent and independent of its culture. Her writings belong to the post-modern literary genre of feminist protest.

Her nameless hero stands not only as a sound ecologist, but she also changes herself into the natural world being one with it. Her voyage into the deep remote setting into the woods in concurrently a voyage into her mindscape. While getting back to the homeland after the elapse of many years, she gets reminded of her-childhood memories. She feels nostalgaic and better 
here than being in the city. All that had occured to her in the urban life have had destructive effects

\section{Bill Ashcroft, Gareth Griffiths and Helen Tiffin : The Empire Writes Back (London : Routledge, 1989) P. 195}

on her survival. Her elopement with her previously married drawing master and the subsequent abortion were all actions that drifted her existence to many ups and downs. When she started dreaming to have the baby, however her partner strained her to spoil the pregnancy. When the foetus was removed from her womb, she felt herself like a killer implicated in a cold-blooded murder as she depicts- "they take the baby out with a fork like a pickle out of a pickle jar." (Atwood 79)

She propounds in her book that the universe is under threat due to human jealousy but there still remains a ray of hope as she briefly says — "There had to be a good kind and a bad kind of everything”

(Atwood 41)

She happens to warn the humanity about the bad kind and it is time for good kind to prevail. If human-being tends to follow a deep ecological perspective to the natural world, respect and love nature and trust that __........ an animal is the soul of an ancestor or the child of a good...." (Atwood 129)

Consequently we would be capable to perceive the importance of nature and that natural resources living in close proximity with nature and stop damaging it. The French revolutionary message — 'Back to Nature' is relevantly reminded here which was delivered by Rousseau, the hero of the movement. This message was later on communicated by the Romantics. 
It would be quite rational to quote the fine stanza from Wordsworth's famous poem 'Lines Written In Early Spring', when he says --

\author{
"If this belief from Heaven be sent, \\ If such be Nature's holy plan, \\ Have I not reason to lament, \\ What man has made of man"
}

Thus there is an everlasting binding between nature and man. If this chain is broken, man has to suffer in every walk of life. Atwood delivers her message in this perspective that humanbeing's wrong steps bring his doom.

In Atwood's novel — 'Surfacing', the blurred floats into the narrator's consciousness and it gives the signal of the beginning of her recovery process, and the search for wholeness, unity of the body and mind, unity of reason and emotion, and the unity of past and present. This internal mental conflict in the narrator's psyche finally disappears after she has realized an experience having the sense of wholeness.

She beautifully projects 'images' and 'symbols' of separation and dualism. One major symbol that represents the idea of unity or wholeness is the 'fish'. This one happens to appear and disappear throughout the narration. Far the narrator, the fish symbolizes wholeness, the unity between mind and body that she is searching out. Fish, like other reptiles, have heads that are directly connected with the body and extend into the shoulders, unlike the human-beings where there is an impediment - the neck. The neck separates the body from head. She has a great liking for the fish and does not like them to be killed as they represent for her 'wholeness and unity'. 
'Neckless head body, the fish is whole' thinks the narrator in part two, she begins to see her problem and her need to resolve it.

Later, the narrator, being alone on the island, has a series of wilderness encounters which have been 'likened to shamanistic initiation rituals'. She undergoes a visionary education where psycho-spiritual experience and sensory perceptions are prescribed as parallel modes of heightened awareness which led to the revision and insight. She realizes that she loves and trusts Joe and feels the child breathing within her womb. She visualizes a future with them. The experience of love for Joe and attachment to her unborn child stirs the "still" emotions within her and helps her see reason as a unified human being. By the end of the novel, the narrator's perceptions of her relation to the world have changed so that she is ready to leave the wilderness to return to the society.

The above discussion leads us to sum-up that Atwood has beautifully scattered the fragrance of her ecologistic sensibility as a very keen observer of the environment and circumstances in her making as a great post-colonial novelist. Being born and brought-up in Canada, she beautifully carries forward the spirit of commonwealth literature. Like a painter, she paints the different colours of multiculturalism and hybridity in her novels. 


\section{Notes and References}

Atwood, Margaret, 'Surfacing (Virago: London, 1979)

Ashcraft, Bill, Gareth Griffiths and Helen Tiffin: The Empire Writes Back (London: Routledge, 1989)

Greg, Garrard, Ecocriticism, London/ New York: Routledge, 2007, print

Ingersol, Earl, G, ed. Margaret Atwood: Conversations (London: Virago, 1992) 